\title{
Conservation initiatives for an endangered migratory passerine: field propagation and release
}

\author{
Rina K. Nichols, Jessica Steiner, Lance G. Woolaver, Elaine Williams \\ A му A. CH в о т and Ken TUININGA
}

\begin{abstract}
The term 'field propagation and release' refers to the breeding of captive adults in large field enclosures, allowing them to raise their young, and then releasing those young from that location. This technique is currently being implemented in Canada as one of several recovery tools for the endangered eastern loggerhead shrike Lanius ludovicianus migrans. During 2001-2007 a total of 360 shrike fledglings were produced in field propagation enclosures and 301 were released from these enclosures. Annual return rates of birds released since 2004 are $2-6.6 \%$. Seventeen released birds have been re-sighted, including 10 birds that have returned to the breeding grounds the following season to produce young with wild mates. The high annual return rate of release birds and the successful integration of these birds into the wild breeding population represent important milestones for the recovery of this population. The management technique we describe here has the potential to be applicable to other species that require natural habitat for breeding and/or are reliant on a suite of parent-learned behaviours that cannot be accommodated for or adequately replicated within intensive close captive-breeding or hand-rearing conditions.
\end{abstract}

Keywords Canada, endangered, field propagation, Lanius ludovicianus, loggerhead shrike, migratory, passerine, soft release

\section{Introduction}

$\mathrm{P}$ asseriformes is the most under-represented Order in avian reintroduction programmes, with $>600$ threatened species and $<35$ projects worldwide (Seddon et al., 2005). Conservation breeding and release of threatened passerines is well documented on islands (Watson et al., 1992; Rocamora et al., 2003; Tweed et al., 2003; Munkwitz et al., 2005; Taylor et al., 2005; Garrett et al., 2007; Leech et al., 2007) but little information is available regarding

Rina K. Nichols (Corresponding author), Jessica Steiner, Lance G. Woolaver and Elaine Williams Wildlife Preservation Canada, 5420 Highway 6 North, Guelph, Ontario, Canada N1E 3N7. E-mail rinanichols@hotmail.com

Аму А. Снавот Department of Biology, Queens University, Kingston, Ontario, Canada

Ken Tuininga Environment Canada, Toronto, Ontario, Canada

Received 27 February 2009. Revision requested 20 April 2009.

Accepted 26 July 2009. their mainland migratory counterparts. As more migratory passerines decline (Hussell, 1992; Lloyd-Evans \& Atwood, 2004; Fuller et al., 2005) specialized techniques will be needed to recover these populations.

The loggerhead shrike Lanius ludovicianus is a mediumsized (45 g) raptor-like passerine occurring throughout North America. There are 11 recognized subspecies, four of which are migratory (Pruitt, 2000). The eastern subspecies L. ludovicianus migrans is listed as endangered in Canada (COSEWIC, 2004), with 31 known breeding pairs in Canada in 2008 (De Smet, pers. comm.; Wildlife Preservation Canada, unpubl. data).

In 1997 the wild population in Canada had decreased to 18 known pairs. Forty-three nestlings were collected from wild nests in Ontario to found a captive population. Within 4 years the captive population had increased to c. 100 birds and a trial field propagation and release programme was initiated. The term 'field propagation and release' refers to the breeding of captive adults in large field enclosures, allowing them to raise their own young, and subsequently releasing those young to the wild from the same location. Ideally, the enclosures are placed within the natural habitat of the species' breeding range. This parent-rearing management technique was specifically developed to accommodate natural behaviours of shrikes and to address challenges that can often arise in intensive breeding facilities and/or hand-rearing conditions, such as imprinting, behaviour modification, low productivity and low survival (Wildlife Preservation Canada, unpubl. data).

Reasons for the decline of L. ludovicianus migrans remain unclear but the main factors may be habitat fragmentation, pesticides, predation, adverse weather events, and mortality along roads (Pruitt, 2000; Environment Canada, 2006). Habitat destruction/alteration and pesticide use have been strongly implicated in population declines in both the USA and Canada (Cadman, 1985; Telfer, 1992; Yosef, 1996). For L. ludovicianus migrans the considerable amount of unoccupied breeding habitat (Chabot, 2001b; Jobin et al., 2005) and high fledging success of pairs on the breeding grounds (Chabot, 2001a) suggest that main causes for decline may not be occurring in the breeding range (Pruitt, 2000). Brooks \& Temple (1990) concluded that low overwinter survival was the main factor in the sharp declines in populations of shrikes in Minnesota, and this is also suspected to be the case for L. ludovicianus migrans in Canada (Pruitt, 2000). 
Research is underway to document the causes of the decline of this population (Cadman, 1985; Environment Canada, 2006), including ongoing studies to determine wintering areas and migratory routes (Chabot, 2006; Wildlife Preservation Canada, unpubl. data). Ultimately, determining the agents of decline and then halting them is the main goal of the recovery of $L$. ludovicianus migrans. In the interim, field propagation and release has been an effective method for maintaining the remnant breeding population until the causes of decline can be identified and reversed in the wild. Once limiting factors have been determined and mitigated, field propagation and release will be a useful tool for increasing the wild population to a self-sustaining level. This minimum viable population size is currently being researched using population viability analysis (Environment Canada, unpubl. data).

\section{Study area}

The programme is releasing parent-reared young at two locations in southern Ontario, Canada: Dyer's Bay, where shrikes have been extirpated within the past 5-7 years, and Carden Alvar, where there is a small breeding wild population of c. 10-14 pairs (Wildlife Preservation Canada, unpubl. data; Fig. 1). Sites were selected in short grassland habitat within the historical range of $L$. ludovicianus migrans in areas where breeding pairs either exist or had only recently been locally extirpated, in accordance with the IUCN Guidelines for Re-Introductions (IUCN, 1998). The suitability of the local habitat was assessed in both sites and surrounding areas prior to establishment of the enclosures.

\section{Methods}

\section{Field enclosures}

The programme started with three field propagation and release enclosures in the Smiths Falls area and has since expanded substantially to 26 enclosures: 14 at Carden and 12 at Dyer's Bay. All enclosures consist of either two or three units made of individual pre-constructed panels that are easily transported to the field site and then bolted together. Enclosures were built around live hawthorn (Crataegus sp.), buckthorn (Rhamnus sp.) or apple (Malus sp.) trees to provide nesting cover and thorns for the shrikes to impale their prey as they would in the wild. Each unit was furnished with perching, impaling branches, nesting material, nest cups and branching for cover to facilitate pair bonding and breeding.

\section{Management of breeding pairs}

From late April to September selected pairs were relocated from the programme's overwintering facilities at the Toronto Zoo, Ingersoll, and the Avian Science and Conservation Centre at McGill University to the field propagation enclosures. Studbook data were maintained by Canadian Association of Zoos and Aquariums and analysed using the Single Population Analysis and Records Keeping System provided by the International Species Information System (Carnio, 2007). During 2001-2004 maximizing genetic diversity formed the basis for choosing birds for pairing, and during 2005-2007 breeding history and experience were also considered.

A guideline for management of captive populations and Species Survival Plan captive breeding is to maintain 90\% of the genetic diversity for more than 200 years (Foose et al., 1986; Soule et al., 1986). At present the captive population is retaining $97.1 \%$ of the genetic diversity of the original wild founders (Carnio, 2007). Offspring from pairs considered of highest genetic priority to the captive population are retained as breeding stock, whereas young from low-genetic priority pairs are candidates for release.

Females and males were initially placed in different units of the same enclosure and separated by a door of wire mesh

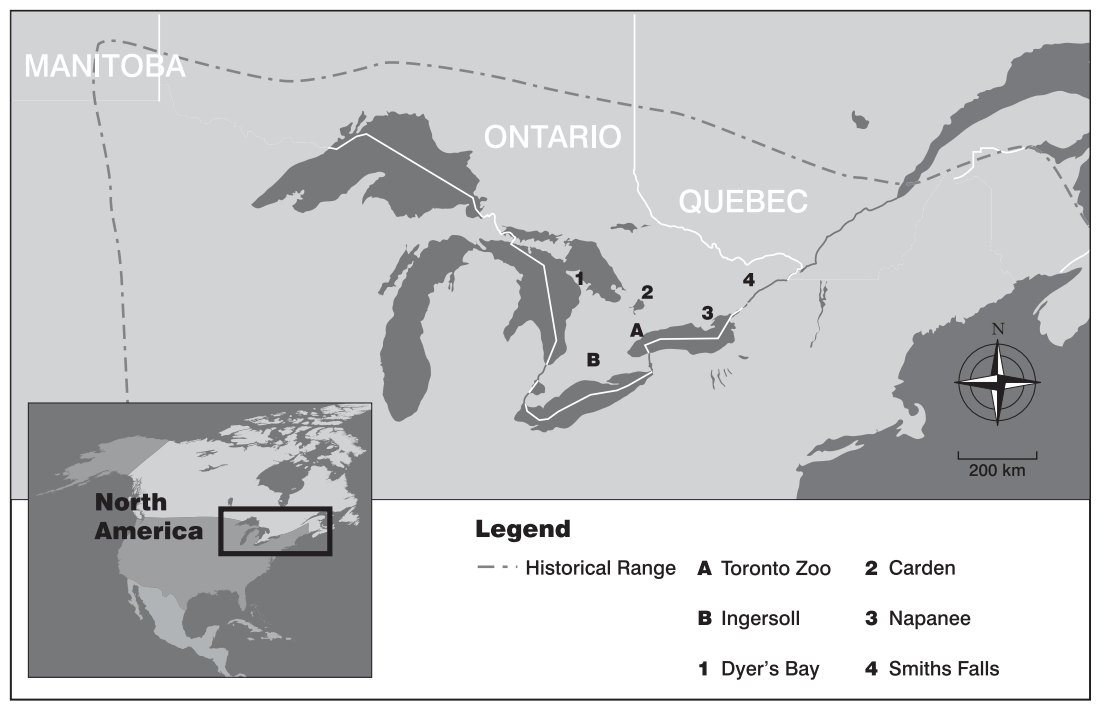

FIG. 1 Canada, showing the historical breeding range of eastern loggerhead shrikes Lanius ludovicianus migrans (within dotted line), locations of the field propagation and release sites (Carden, Dyer's Bay and Smiths Falls), the overwintering facilities (Toronto Zoo and Ingersoll) and the remaining wild populations (Napanee and Carden). 
to avoid any potential aggressive interactions. Once a pair was observed courtship-feeding or exhibiting other signs of courtship, the doors were opened and both birds were allowed access to the full enclosure. Birds were provided with food (crickets, meal-worms and mice) in large feeding corrals, and water twice daily. Feeding amounts varied depending on stage of breeding, age and number of birds in the enclosure (WPC, 2007a). Detailed observations of at least 20 minutes, $1-2$ times per day, were made of each pair from their arrival at the field site throughout the breeding season to ensure the adults were caring for their young. All disturbance to the pairs and their offspring was kept to an absolute minimum.

\section{Management of fledglings and release birds}

Once young fledged their development was monitored daily to ensure that they were being fed and taught to hunt by their parents. Fledglings were separated from their parents when 37-49 days old, the approximate age at which they become independent of parental care in the wild (Pruitt, 2000; Chabot, 2001a). Once the young were seen to feed on their own they were moved to a predetermined release enclosure where they were grouped with other release candidates of approximately the same age. On the day of transfer to a release enclosure fledglings were banded and morphometric data collected following established protocols (WPC, 2007b).

\section{Pre-release}

After banding, fledglings from different broods were placed in the same enclosure but separated within units for 1-2 days for acclimation. After this all young had access to the full enclosure and were subsequently released in groups of 6-12. Releasing young in large groups of mixed broods approximated wild behaviour whereby young from different nests travel together post-fledging (C. Grooms, pers. comm.).

Release birds were kept within the release enclosures for 7-10 days for pre-release training. On each of these days training consisted of placing meal-worms on a shelf just inside the release doors at the time of day they would eventually be released. This encouraged shrikes to feed near the release doors. Pre-release training also included the provision of live mice. Thus the fledglings developed strong hunting skills and the ability to kill and impale live vertebrate prey. Daily observations ensured that all young were feeding on their own prior to release.

\section{Release}

Healthy young were released at 44-66 days of age. Field propagation enclosures were transformed into release enclosures prior to receiving any young by placing shelves under the inside and outside of the release door and by adding branches to the outside of the enclosure to provide perching sites near the release door.

Releases began 2-4 hours before dusk. Bowls containing meal-worms were placed on the outside shelf, food was placed in outdoor feeding corrals and the release door was opened. Observers watched the release door from a hidden observation point at least $60 \mathrm{~m}$ away and recorded detailed behavioural notes during the release.

The full diet was placed in the outside corrals for at least 1 week post-release, continuing with both morning and afternoon feeds. After this, the amount of supplemental food was gradually decreased according to how many shrikes were still in the area. Staff and volunteers monitored the release site and surrounding area daily until the last bird had left the release site.

\section{Results}

A total of 360 fledglings were produced in the field propagation and release programme during 2001-2007. The number of young produced annually increased as the programme expanded, from 10 young produced from three pairs in 2001 to 111 young produced from 23 pairs in 2007 (Table 1). Since 2001, 38 young have been retained to augment the captive population, six were not released because of injuries and 16 died soon after fledging (Table 1).

The number of pairs to double-brood successfully has also increased since 2001 (Table 2), resulting in an increased number of young produced per breeding pair per season, from 3.3 fledglings per breeding pair in 2001 to 7.4 fledglings per breeding pair in 2006 (Table 2). Mean number of nestlings and fledglings produced was highest in 2006. Financial constraints in the 2007 season led to management having to prevent double-brooding in eight of the 23 pairs.

A total of 301 young shrikes have been released in Ontario since 2001. The number of young released each season increased substantially from 10 in 2001 to 111 in 2006 and 91 in 2007, with more fledglings released in 2006 than all previous years combined (Table 1). All the released fledglings were parent-reared at the field sites and released from the location where they were raised.

There have been 17 separate confirmed sightings of released birds. Three lone birds were sighted during migration and 14 returned to the breeding grounds in Ontario. Ten of these birds (seven females and three males) have integrated with the wild population at Carden and successfully produced wild fledglings. A female released in Dyer's Bay in 2004 paired with a wild male in 2005 and successfully fledged six young, producing one of the largest wild broods of the season (Wildlife Preservation Canada, unpubl. data). A female released in 2005 nested with a wild male in 2006 and was later observed feeding three 
TABLE 1 Number of eastern loggerhead shrike Lanius ludovicianus migrans fledglings produced and released at the field propagation sites in Ontario (Fig. 1) during 2001-2007.

\begin{tabular}{|c|c|c|c|c|c|c|}
\hline \multirow[b]{2}{*}{ Year } & \multirow{2}{*}{$\begin{array}{l}\text { No. of pairs } \\
\text { (\% of pairs to } \\
\text { fledge young) }\end{array}$} & \multirow{2}{*}{$\begin{array}{l}\text { Total no. of } \\
\text { fledglings } \\
\text { produced }\end{array}$} & \multirow{2}{*}{$\begin{array}{l}\text { No. of } \\
\text { fledglings retained } \\
\text { to augment captive } \\
\text { population }\end{array}$} & \multicolumn{2}{|c|}{ No. of fledglings } & \multirow[b]{2}{*}{$\begin{array}{l}\text { No. of young } \\
\text { released }\end{array}$} \\
\hline & & & & $\begin{array}{l}\text { Injured } \\
\text { (not released) }\end{array}$ & $\begin{array}{l}\text { Died post- } \\
\text { fledging }\end{array}$ & \\
\hline 2001 & $3(100)$ & 10 & 0 & 0 & 0 & 10 \\
\hline 2002 & $5(100)$ & 19 & 2 & 2 & 1 & 14 \\
\hline 2003 & $20(15)$ & 4 & 4 & 0 & 0 & 0 \\
\hline 2004 & $20(45)$ & 34 & 8 & 0 & 0 & 26 \\
\hline 2005 & $20(45)$ & 53 & 2 & 2 & 0 & 49 \\
\hline 2006 & $24(71)$ & 129 & 16 & 1 & 1 & 111 \\
\hline 2007 & $23(83)$ & 111 & 6 & 0 & 14 & 91 \\
\hline Total & & 360 & 38 & 5 & 16 & 301 \\
\hline
\end{tabular}

fledglings. Two male birds released in 2006 paired with wild females in 2007 and together produced a minimum of seven fledglings. In 2008, six release birds (one male and five females) returned to pair with wild counterparts and in total produced at least 18 young. Two of these females had been released in Carden in 2006 and were siblings from the same brood. The other four birds were released (two at Carden and two at Dyer's Bay) in 2007.

The overall return rate of release birds from 2001 to 2007 was $4.6 \%$ (Table 3 ). Since 2004 the annual return rates of juveniles released the previous season were $2-6.6 \%$ (Table 3).

\section{Discussion}

The number of fledglings produced increased substantially each year, with the exception of the 2003 season. Productivity of shrikes housed in our field propagation enclosures was slightly better than that achieved by wild shrike populations in the adjacent area (Wildlife Preservation Canada, unpubl. data). This suggests that the environment of our field propagation enclosures approximates conditions conducive to shrike reproduction in nature and is relatively stress free, with the added benefit of predator exclusion and plentiful food supply. This increased productivity may have resulted from the implementation of several adaptive management techniques, which included an increase in enclosure height by $0.65 \mathrm{~m}$, aggregating enclosures to stimulate breeding, improving overwintering conditions and expanding genetic pairing specifications to include breeding experience and history (Wildlife Preservation Canada, unpubl. data).

Low productivity in 2003 was probably due to a combination of late timing (pairing occurred in early to mid June) and the stress of repeated handling associated with West Nile Virus inoculation and testing that season. In the following seasons field propagation pairing was begun in the first week of May, which more closely approximates when breeding begins in wild shrikes. In 2008 West Nile Virus inoculations were carried out prior to the breeding season and did not affect breeding.

Release techniques for the eastern loggerhead shrike were modified from successful earlier reintroduction projects such as those for the Mauritius pink pigeon Columba

TABLE 2 Number of field-propagated pairs of eastern loggerhead shrikes in Ontario (Fig. 1) to double-brood successfully and mean number of nestlings and fledglings produced per breeding pair during 2001-2007.

\begin{tabular}{lllll}
\hline & $\begin{array}{l}\text { No. of pairs to } \\
\text { double-brood } \\
\text { successfully }\end{array}$ & $\begin{array}{l}\text { Mean no. of } \\
\text { nestlings produced } \\
\text { per breeding pair } \pm \text { SD } \\
\text { (range, } \mathrm{n})^{1}\end{array}$ & $\begin{array}{l}\text { Mean no. of fledglings } \\
\text { produced per breeding } \\
\text { pair } \pm \text { SD (range, } \mathrm{n})\end{array}$ \\
\hline 2001 & No. of pairs & 0 & $3.7 \pm 0.6(3-4,3)$ & $3.3 \pm 1.2(3-4,3)$ \\
2002 & 3 & 1 & $5.3 \pm 1.3(4-7,4)$ & $5.0 \pm 1.4(4-7,4)$ \\
2003 & 20 & 0 & $1.3 \pm 0.6(1-2,3)$ & $1.3 \pm 0.6(1-2,3)$ \\
2004 & 20 & 2 & $4.1 \pm 1.4(2-6,9)$ & $3.7 \pm 1.9(0-6,9)$ \\
2005 & 20 & 5 & $6.2 \pm 1.9(4-9,9)$ & $6.0 \pm 2.6(4-9,9)$ \\
2006 & 24 & 10 & $7.6 \pm 2.6(3-11,17)$ & $7.4 \pm 2.7(3-11,17)$ \\
$2007^{2}$ & 23 & 8 & $6.5 \pm 2.4(2-11,19)$ & $5.8 \pm 2.2(2-10,19)$ \\
\hline
\end{tabular}

${ }^{1}$ Includes second nesting

${ }^{2}$ Because of financial constraints, breeding in 2007 was limited in eight of the 23 pairs to a single clutch, although all pairs began building second nests 
TABLE 3 Annual return rates of fledgling eastern loggerhead shrikes released to the wild in Ontario (Fig. 1) during 2001-2007.

\begin{tabular}{lcll}
\hline & $\begin{array}{l}\text { No. } \\
\text { released }\end{array}$ & $\begin{array}{l}\text { No. returned } \\
\text { in subsequent } \\
\text { breeding seasons }\end{array}$ & $\begin{array}{l}\text { Annual } \\
\text { return } \\
\text { rate (\%) }\end{array}$ \\
\hline 2001 & 10 & 0 & 0 \\
2002 & 14 & 0 & 0 \\
2003 & 0 & 0 & 0 \\
2004 & 26 & 1 & 3.8 \\
2005 & 49 & 1 & 2.0 \\
2006 & 111 & 6 & 5.4 \\
2007 & 91 & 6 & 6.6 \\
Total/Mean & 301 & 14 & 4.6 \\
\hline
\end{tabular}

mayeri and echo parakeet Psittacula echo (Jones et al., 1992; Woolaver et al., 2000). As a so-called soft or delayed release, it was critical that the release birds were provided with a recognizable food source whilst they learnt to rely on wild food. Similarly, supplemental feeding was a critical component of the San Clemente loggerhead shrike Lanius ludovicianus mearnsi reintroduction and was particularly important during the first week post-release (D. Brubaker, pers. comm.). It was also important that the enclosure remained a safe location and shrikes were never forced to leave the enclosure during the release.

Because documented return rates of wild juvenile loggerhead shrikes are 0.8-1.2\% (Haas, 1995; Collister \& De Smet, 1997) sightings of returning birds were not expected until at least 100 birds had been released ( $1 \%$ return rate). Thus, it was not unexpected that we began to see returning birds in spring 2005, when slightly more than 100 juveniles had been released. Since 2004 annual return rates of release birds have been $2-6.6 \%$, higher than juvenile return rates noted in wild migratory loggerhead shrike populations. In south-eastern Alberta and south-western Manitoba return rates of wild juvenile shrikes in the year following banding were 1.2 and $0.85 \%$, respectively (Collister \& De Smet, 1997). A 1\% return rate was recorded in Indiana (Burton, 1990), 1.1\% in Missouri (Kridelbaugh, 1983) and $0.8 \%$ in North Dakota (Haas, 1995), and Brooks \& Temple (1990) recorded no returns from 196 nestlings banded in Minnesota. The average annual return rate of our release birds ( $4.6 \%$ ) is thus four times higher than return rates for other wild juvenile migratory shrikes.

In 2008, 31 wild pairs were observed nesting in Canada. In the Carden area six of the 16 pairs consisted of a release bird paired with a wild bird, accounting for c. $40 \%$ of the pairings in that area and c. $20 \%$ of all known pairs in the country. This is a substantial contribution by fieldpropagated individuals to the wild population in Canada.

Nearly all passerine releases have been carried out on islands, where only a relatively small number $(<50)$ of release individuals are needed to colonize or recolonize the release area (Tweed et al., 2003; Taylor et al., 2005; Jamieson et al., 2007; Leech et al., 2007). In these situations the survival and productivity of release birds have been significantly enhanced by provisioning them with supplemental food at the release site for long periods of time (including during the breeding season), predator control or eradication, and post-release monitoring and radiotracking (Wanless et al., 2002; Heath et al., 2008). For migratory species these types of management techniques are either extremely difficult to implement or may not be logistically feasible. In our study release birds tended to stay around the release area for a few days to several weeks, where they had access to supplemental food. However, the birds had no direct support once they left the immediate area. Post-release monitoring occurred via observations and, more recently, through radio-telemetry. Preliminary telemetry research in the Carden area in 2007 found that survival from release to the onset of migration (6-8 weeks) was $76.5 \%$ (J.F. Crowley, A.M. Argue, T.I. Imlay, B.J.M. Stutchbury, J.C. Steiner \& D.R. Norris, unpubl. data), similar to the post-release survival rates noted for passerine reintroductions on islands of $63-100 \%$ (Tweed et al., 2003; Leech et al., 2007). These rates are high relative to postfledging survival rates reported in wild passerine populations (53\%, Naef-Daenzer et al., 2001; 56-63\%, Wells et al., 2007; 16\%, Adams et al., 2006; 33\%, Berkeley et al., 2007) and suggest that the fitness level of field-propagated young is satisfactory. By not releasing young until $43+$ days old we are maximizing their protection, and hence survival, during the early post-fledgling period when wild shrike mortality is $33-53 \%$ (Burton, 1990; Collister, 1994).

Successful release of migratory passerines carries the significant additional challenge posed by extremely high first-year mortality during migration and overwintering. Band returns suggest that only $10-20 \%$ of wild hatch-year passerines survive migration and return to their natal area to breed (J. McCracken, Bird Studies Canada, pers. comm.; E. Morton, Smithsonian Migratory Bird Center, pers. comm.). To counter this high mortality our project aims to release substantial numbers of birds $(>100$ per year). Number released is a significant predictor of successful population re-establishment (Beck et al., 1994; Wolf et al., 1996; Green, 1997). Releases of the migratory peregrine falcon Falco peregrinus (anatum race) were carried out in Canada in large numbers (10os per year for $>20$ years) and, coupled with banning the use of DDT, resulted in successful population increase and down-listing of the species (Holroyd \& Banasch, 1990; COSEWIC, 2007).

The high return rate of our release birds compared to wild migratory juveniles and the successful integration of release birds within the wild breeding population are important for the recovery of this population. The management technique we describe could also be used for other similarly endangered migratory passerines and may be applicable to other taxa that require natural habitat for 
breeding and/or are reliant on a suite of parent-learned behaviours that cannot be accommodated for, or adequately replicated, within intensive captive-breeding or hand-rearing conditions.

\section{Acknowledgements}

We thank all the individuals and partner organizations of the field propagation and release effort, including Ross Snider, the Avian Science and Conservation Centre at McGill University, Toronto Zoo, Bird Studies Canada, Canadian Cattleman's Association, Canadian Wildlife Service, Canadian Association of Zoos and Aquariums (John Carnio), the Couchiching Conservancy, Bill Dobson and Linda Hynes, Bill and Barb McNair, the Ontario Ministry of Natural Resources and Neil and Carolyn Turnbull. Robert Wenting was the originator of the field propagation and release concept. Other individuals who have provided significant contributions to the programme include Tom Mason, Jon McCracken, Letitia McRitchie, Murray Smith and Merilee Temple. Funding was provided by Environment Canada, Wildlife Preservation Canada and French Rabbit, as well as in-kind support from the above-noted individuals and partner organizations. Other advisers to the programme include Kay McKeever and the San Clemente Loggerhead Shrike Recovery Program. The field interns and volunteers, although too numerous to mention individually, have been the backbone of the project. Comments from Philip Seddon, Eugene Morton, Bridget Stutchbury, Murray Smith, Ross Snider and an anonymous reviewer greatly improved an earlier draft. All required research permits were obtained (\#POS 111, \#CA 0129 and Banding \#10809), and research ethics were approved by the Canadian Wildlife Service of Environment Canada.

\section{References}

Adams, A., Skagen, S. \& Savidge, J. (2006) Modelling postfledging survival of lark buntings in response to ecological and biological factors. Ecology, 87, 178-188.

Beck, B.B., Rapaport, L.G., Stanley Price, M.R. \& Willon, A.C. (1994) Reintroduction of captive-born animals. In Creative Conservation: Interactive Management of Wild and Captive Animals (eds P.J.S. Olney, G.M. Mace \& A.T.C. Feistner), pp. 265286. Chapman \& Hall, London, UK.

Berkeley, L., McCarty, J. \& Wolfenbarger, L. (2007) Postfledging survival and movement in dickcissels (Spiza americana): implications for habitat management and conservation. The Auk, 124, 396-409.

Brooks, B.L. \& Temple, S.A. (1990) Dynamics of a loggerhead shrike population in Minnesota. Wilson Bulletin, 102, 441-450.

BurTON, K.M. (1990) 1989. Loggerhead shrike update. Indiana Audubon Quarterly, 68, 57-58.

Cadman, M. (1985) Status Report on the Loggerhead Shrike in Canada (Lanius ludovicianus). Committee on the Status of Endangered Wildlife in Canada report, Ottawa, Canada.
CARnio, J. (2007) Eastern Loggerhead Shrike Studbook Report 2006/ 2007. Unpublished report to Eastern Loggerhead Shrike Recovery Team, Canadian Wildlife Service, Ontario, Canada.

Снавот, A.A. (2006) Demography, migration and population genetics of the loggerhead shrike (Lanius ludovicianus) in eastern North America. PhD thesis, Queen's University, Kingston, Canada.

Chaвот, A.A., Bird, D.M. \& Titman, R.D. (2001a) Breeding biology and nest success of loggerhead shrikes in Ontario. Wilson Bulletin, 113, 285-289.

Cнавот, A.A., Titman, R.D. \& Bird, D.M. (2001b) Habitat use by loggerhead shrikes in Ontario and Quebec. Canadian Journal of Zoology, 79, 916-925.

Collis TER, D.M. (1994) Breeding ecology and habitat preservation of the loggerhead shrike in south-eastern Alberta. MSc thesis, University of Calgary, Calgary, Canada.

Collister, D.M. \& De SMet, K. (1997) Breeding and natal dispersal in the loggerhead shrike. Journal of Field Ornithology, 68, 273-282.

COSEWIC (Committee on the Status of Endangered Wildlife in CAnAda) (2004) Canadian Species at Risk, May 2004. Committee on the Status of Endangered Wildlife in Canada, Ottawa, Canada.

COSEWIC (Committee on the Status of Endangered Wildlife in CANADA) (2007) COSEWIC Assessment and Update Status Report on the Peregrine Falcon Falco peregrinus in Canada. Committee on the Status of Endangered Wildlife in Canada, Ottawa, Canada. Http://www.sararegistry.gc.ca/status/status_e.cfm [accessed 1 November 2008].

Environment CANAda (2006) Recovery Strategy for the Loggerhead Shrike, migrans Subspecies (Lanius ludovicianus migrans), in Canada [Proposed]. Species at Risk Act Recovery Strategy Series. Environment Canada, Ottawa, Canada.

Foose, T.J., Lane, R., Flessness, N.P., Rabb, G.B. \& Read, B. (1986) Propagation plans. Zoo Biology, 5, 139-146.

Fuller, R.J., Noble, D.G., Smith, K.W. \& Vanhinsbergh, D. (2005) Recent declines of populations of woodland birds in Britain: a review of possible causes. British Birds, 98, 116-143.

Garrett, L.J.H., Jones, C.G., Cristinacce, A. \& Bell, D. (2007) Competition or coexistence of reintroduced, critically endangered Mauritius fodies and invasive Madagascar fodies in lowland Mauritius. Biological Conservation, 140, 19-28.

Green, R.E. (1997) The influence of numbers released on the outcome of attempts to introduce exotic bird species to New Zealand. The Journal of Animal Ecology, 66, 25-35.

HaAs, C.A. (1995) Dispersal and use of corridors by birds in wooded patches on an agricultural landscape. Conservation Biology, 9, $845-854$.

Heath, S.R., Kershner, E.L., Cooper, D.M., Lynn, S., Turner, J.M., WARnock, N. et al. (2008) Rodent control and food supplementation increase productivity of endangered San Clemente loggerhead shrikes (Lanius ludovicianus mearnsi). Biological Conservation, 141, 2506-2515.

Holroyd, G.L. \& BANASCH, U. (1990) The reintroduction of the peregrine falcon, Falco peregrinus anatum, into southern Canada. Canadian Field Naturalist, 104, 203-208.

Hussell, D.J.T., Mather, M.H. \& Sinclair, P.H. (1992) Trends in numbers of tropical and temperate wintering migrant land-birds in migration at Long Point, Ontario, 1961-1988. In Ecology and Conservation of Neotropical Migrant Land-birds (eds J.M. Hagna, III \& D.W. Johnston), pp. 101-130. Smithsonian Institution Press, Washington, DC, USA.

IUCN (1998) IUCN Guidelines for Re-Introductions. Prepared by the IUCN/SSC Re-Introduction Specialist Group. IUCN, Gland, Switzerland, and Cambridge, UK. 
Jamieson, I.G., Tracy, L.N., Fletcher, D. \& Armstrong, D.P. (2007) Moderate inbreeding depression in a reintroduced population of North island robins. Animal Conservation, 10, 95-102.

Jobin, B., Grenier, M. \& Laporte, P. (2005) Using satellite imagery to assess breeding habitat availability of the endangered loggerhead shrike in Quebec. Biodiversity and Conservation, 14, $81-95$.

Jones, C.G., Swinnerton, K.J., Taylor, C.J. \& Mungroo, Y. (1992) The release of captive-bred pink pigeons Columba mayeri in native forest in Mauritius. A progress report July 1987-June 1992. Dodo, 28, 92-125.

KRIDElBAUGH, L. (1983) Nesting ecology of the loggerhead shrike in central Missouri. Wilson Bulletin, 95, 303-308.

Leech, T.J., Craig, E., Beaven, B., Mitchell, D.K. \& Seddon, P.J. (2007) Reintroduction of rifleman Acanthisitta chloris to Ulva Island, New Zealand: evaluation of techniques and population persistence. Oryx, 41, 369-375.

Lloyd-Evans, T.L. \& ATwood, J.L. (2004) 32 years of changes in passerine numbers during spring and fall migrations in coastal Massachusetts. Wilson Bulletin, 116, 1-16.

Munkwitz, N.M., Turner, J.M., Kershner, E.L., Farabaugh, S.M. \& Heath, S.R. (2005) Predicting release success of captivereared loggerhead shrikes (Lanius ludovicianus) using pre-release behavior. Zoo Biology, 24, 447-458.

Naef-Daenzer, B., Widmer, F. \& Nuber, M. (2001) Differential post-fledging survival of great and coal tits in relation to their condition and fledging date. The Journal of Animal Ecology, 70, $730-738$.

PrUit T, L. (2000) Loggerhead Shrike Status Assessment. Unpublished Report. US Fish and Wildlife Service, Bloomington, USA.

Rocamora, G., Henriette, E. \& Constance, P. (2003) Successful conservation introduction of the Seychelles white-eye on Fregate island, Seychelles. Reintroduction News, 22, 46.

Seddon, P.J., Soorae, P.S. \& Launay, F. (2005) Taxonomic bias in reintroduction projects. Animal Conservation, 8, 51-58.

Soulé, M., Gilpin, M., Conway, W. \& Fosse, T. (1986) The millennium ark: how long the voyage, how many state rooms, how many passengers? Zoo Biology, 5, 101-113.

Taylor, S.S., Jamieson, I.G. \& Armstrong, D.P. (2005) Successful island reintroductions of New Zealand robins and saddlebacks with small numbers of founders. Animal Conservation, $8,415-420$.

Telfer, E.S. (1992) Habitat change as a factor in the decline of the western Canadian loggerhead shrike, Lanius ludovicianus, population. Canadian Field-Naturalist, 106, 321-326.

Tweed, E.J., Foster, J.T., Woodworth, B.L., Oesterle, P., Kuehler, C., Lieberman, A.A. et al. (2003) Survival, dispersal, and home-range establishment of reintroduced captive-bred puaiohi, Myadestes palmeri. Biological Conservation, 111, 1-9.
W anless, R.M., Cunningham, J., Hockey, P.A.R., Wanless, J., White, R.W. \& Wiseman, R. (2002) The success of a softrelease reintroduction of the flightless Aldabra rail (Dryolimnas [cuvieri] aldabranus) on Algebra Atoll, Seychelles. Biological Conservation, 107, 203-210.

Watson, J., Warman, C., Todd, D. \& Labondallon, V. (1992) The Seychelles magpie robin Copsychus sechellarum: ecology and conservation of an endangered species. Biological Conservation, 61, 93-106.

Wells, K.M.S., Ryan, M.R., Millspaugh, J.J., Thompson, F.R. \& Hub bard, M.W. (2007) Survival of post-fledging grassland birds in Missouri. Condor, 109, 781-794.

Wolf, C.M., Griffith, B., Reed, C. \& Temple, S.A. (1996) Avian and mammalian translocations: update and reanalysis of 1987 survey data. Conservation Biology, 10, 1142-1154.

Woolaver, L., Jones, C.G., Swinnerton, K., Murray, K., LAlinde, A., BirCh, D. et al. (2000) The release of captive bred echo parakeets to the wild, Mauritius. Re-Introduction News, 19, $12-15$.

WPC (Wildlife Preservation Canada) (2007a) Experimental Field Propagation Husbandry Protocols for Eastern Loggerhead Shrike. Unpublished Report. Wildlife Preservation Canada, Guelph, Canada.

WPC (Wildlife Preservation Canada) (2007b) Eastern Loggerhead Shrike Banding Protocol. Unpublished Report. Wildlife Preservation Canada, Guelph, Canada.

Yosef, R. (1996) Loggerhead shrike (Lanius ludovicianus). In The Birds of North America (eds A. Poole \& F. Gill). Number 231. Academy of Natural Sciences, Philadelphia, and American Ornithologists' Union, Washington, DC, USA.

\section{Biographical sketches}

RiNA K. NiCHOLS has worked on conservation projects in Mauritius, New Zealand and Madagascar, focusing on reintroductions and ecology of threatened species. Jessica STEINER has worked on captive-breeding and threatened species programmes in Mauritius, Australia and Canada. Lance G. Woolaver is a member of the IUCN Reintroduction Specialist Group. His research interests also include the ecology and genetics of threatened raptors. ELAINE Williams has $>18$ years of experience managing the conservation and recovery of threatened species, applied scientific research and training programmes. Аму А. Снавот has conducted research on shrikes throughout eastern Canada and the USA and has been a scientific adviser to the Shrike Recovery Team since the mid 1990s. Ken Tuininga is chair of the Eastern Loggerhead Shrike Recovery Team and involved in a variety of other wildlife and plant programmes. 